\title{
Peningkatan Berat Badan dengan Penggunaan Kontrasepsi KB Suntik 1 Bulan
}

\author{
Wiwi Sartika, Siti Qomariah, Sara Herlina \\ Universitas Abdurrab Pekanbaru, Jalan Riau Ujung No.73, 0813-6524-4454 \\ Email: wiwi.sartika@univrab.ac.id
}

\begin{abstract}
ABSTRAK
Indonesia merupakan urutan ke 5 dengan jumlah penduduk terbanyak yaitu 249 juta. Upaya untuk mengurangi jumlah penduduk dapat dilakukan pemakaian kontrasepsi. Peserta KB di Indonesia lebih banyak memilih Kontrasepsi Suntik sebagai alat kontrasepsi yaitu sebanyak 4.128.115 orang. Pemilihan kontrasepsi KB Suntik 1 Bulan ini dikarenakan tingkat kegagalan pada suntik KB 1 bulan bisa kurang dari 1\% jika digunakan dengan benar dan sesuai waktunya. Tujuan penelitian ini adalah untuk mengetahui peningkatan berat badan (BB) dengan penggunaan kontrasepsi KB suntik 1 bulan di BPM Murtina Wita Pekanbaru. Jenis Penelitian yang digunakan adalah cross sectional dengan teknik pengambilan sampel accidental sampling dengan jumlah sampel 250 orang. Hasil analisis univariat didapatkan mayoritas responden mengalami peningkatan BB sebanyak 157 orang. Hasil analisis bivariat didapatkan hasil uji chi-square diperoleh nilai $P$ value 0,000 $(<0,05)$ yang artinya ada hubungan peningkatan Berat Badan (BB) pada akseptor KB Suntik 1 Bulan di BPM Murtina Wita Pekanbaru. Diharapkan petugas kesehatan mengetahui pola dasar pemilihan KB dan dapat membantu masyarakat khususnya WUS (Wanita Usia Subur) untuk memilih jenis KB.

Kata Kunci: berat badan; kontrasepsi; KB suntik 1 bulan
\end{abstract}

\section{The Increase of Body Weight with the Use of 1-Month Injectable Contraception}

\begin{abstract}
Indonesia is $5^{\text {th }}$ ranked with the largest population of 249 million. Efforts to reduce the population can be done by using contraception. Family Planning participants in Indonesia mostly choose injectable contraception as a contraceptive, there are 4,128,115 people. The choice of 1-month injectable contraception is because the failure rate for 1-month contraceptive injections can be less than $1 \%$ if used correctly and on time. The purpose of this study was to determine the increase in body weight in 1-month injection contraception at Murtina Wta Maternal Clinic of Pekanbaru. The type of research used cross sectional with accidental sampling technique with a sample of 250 people. The results of the univariate study of the majority of respondents experienced an increase in body weight as many as 157 people. Results of Bivariate analysis Based on the results of the chi-square test gained the $p$ value of $0.000(<0.05)$, which means there is an increase in body weight in 1-month injectable contraception's acceptors at Murtina Wta of Pekanbaru. It is hoped that health workers will know the basic pattern of contraception selection and can help the community, especially women of childbearing age to choose contraception.
\end{abstract}

Keywords: family planning ;injection 1 month; weight gain 


\section{LATAR BELAKANG}

Data World Health Organization (WHO) jika dibandingkan dengan Negara ASEAN lainnya, penggunaan alat kontrasepsi di Indonesia sebesar $61 \%$ sudah melebihi ratarata ASEAN (58,1\%). Akan tetapi masih lebih rendah dibandingkan Vietnam (78\%), Kamboja (79\%) dan Thailand (80\%). Padahal jumlah Wanita Usia Subur (WUS) tertinggi di ASEAN adalah Indonesia yaitu 65 juta orang (Kemenkes, 2013).

Indonesia merupakan urutan ke 5 dengan jumlah penduduk terbanyak yaitu 249 juta. Upaya untuk mengurangi jumlah penduduk dapat dilakukan pemakaian kontrasepsi. peserta KB di Indonesia lebih banyak memilih Kontrasepsi Suntik sebagai alat kontrasepsi yaitu sebanyak 4.128.115 orang. Hasil Survei Demografi dan Kesehatan Indonesia (SDKI) tahun 2017, jumlah keseluruhan akseptor KB pada tingkat Nasional 22.682.255 yang terbesar akseptor KB suntik sebanyak 12.562 .106 (55,38\%), pil 5.611.936 $(24,74 \%), \quad$ IUD 2.223.291 (9,8\%), MOW 972.959 (4,29\%), implant 687.689 (3.03\%), kondom $162.252 \quad(0,71 \%)$, MOP 102.166 $(0,45 \%)$, diafragma $21.011(0,09 \%)$, dan cara tradisonal $329.644(1,45 \%)$. Di tingkat Jawa Timur jumlah akseptor KB semua metode 3.956.078, akseptor suntik 2.094.166 (52,93\%), pil $894.192(22,6 \%)$, IUD 515.503 (13,03\%), MOW 265.213 (6,7\%), implant 115.060 (2,95\%), kondom $23.554 \quad(0,59 \%)$, dan diafragma 107 (0,003) (Yuningsih.R.F, 2019)

Pemilihan Kontrasepsi oleh wanita usia subur yang sesuai keinginan sangat penting, salah satu kontrasepsi yang banyakdipilih adalah KB suntikan baik 1 bulan maupun 3 bulan, karena suntik merupakan alat kontrasepsi yang praktis, aman,murah. Faktor yang mempengaruhi dalam menggunakan $\mathrm{KB}$ suntik, antara lain yaitu: Pengetahuan, Pendidikan, Umur, Media Informasi, Ketersediaan alat, Petugas Kesehatan, Dukungan Suami (Dewi Astuti, 2015).

Kontrasepsi suntik memiliki efek samping diantaranya yaitu terganggunya pola haid, terlambat kembalinya kesuburan setelah penghentian pemakaian, dan peningkatan berat badan, peningkatan tekanan darah. permasalahan kenaikan berat badan merupakan efek samping yang sering ditemkan pada penggunaan kontrasepsi suntik. Masalah yang timbul seperti dari peningkatan berat badan adalah masalah kesehatan. kontrasepsi hormonal jika digunakan dalam jangka waktu lama akan memberikan efek samping yang kurang baik bagi kesehatan, seperti penggunaan obat-obatan (Uun Undiarti, Suherni, 2015)

Masalah yang timbul seperti dari peningkatan berat badan adalah masalah kesehatan. KB hormonal memang dapat menyebabkan sedikit peningkatan berat badan, namun tidak sampai membuat tubuh mengalami obesitas. Pertambahan berat badan ini disebabkan oleh kandungan hormon dalam KB hormonal yang dapat meningkatkan nafsu makan dan menyebabkan penumpukan cairan di dalam tubuh. kontrasepsi hormonal jika digunakan dalam jangka waktu lama akan memberikan efek samping yang kurang baik bagi kesehatan. Tujuan dari penelitian ini adalah untuk mengetahui peningkatan berat badan dengan penggunaan kontrasepsi KB Suntik 1 Bulan BPM Murtina Wita Pekanbaru.

\section{METODE}

Penelitian ini termasuk dalam penelitian kuantitatif dengan menggunakan desain penelitian cross sectional. Penelitian ini dilaksanakan di BPM Murtinawita. Sampel pada penelitian ini adalah semua ibu yang menggunakan KB berjumlah 250 orang di BPM Murtina Wita Pekanbaru dengan accidental sampling. Sampel dalam penelitian ini adalah ibu yang menggunakan KB yang berkunjung di BPM Murtina Wita Pekanbaru pada saat penelitian dilakukan. Instrumen yang digunakan adalah kuesioner. Analisis yang digunakan dalam penelitian ini adalah univariat dan bivariat. 
HASIL

Hasil penelitian digambarkan dalam tabel berikut ini;

Tabel 1 Distribusi Frekuensi Peningkatan Berat Badan dan Suntik

\begin{tabular}{ccc}
\hline Variabel & $\mathrm{n}$ & $\%$ \\
\hline Peningkatan BB & & \\
Tidak Meningkat & 93 & 37,2 \\
Meningkat & 157 & 62,8 \\
\hline Total & 250 & 100 \\
\hline
\end{tabular}

\begin{tabular}{lll}
\hline Suntik KB 1 Bulan & & \\
Tidak & 115 & 46,0 \\
Ya & 135 & 54,0 \\
\hline Total & 250 & 100 \\
\hline
\end{tabular}

Tabel 1 menunjukkan bahwa sebagian besar Responden mengalami peningkatan $\mathrm{BB}$ dengan jumlah 157 orang dengan 62,8\%. Mayoritas responden menggunakan suntik KB 1 bulan sebanyak 135 orang 54, $0 \%$.

\section{Hubungan KB Suntik 1 bulan dengan Peningkatan BB digambarkan dalam tael berikut ini;}

Tabel 2. Peningkatan berat badan dengan penggunaan kontrasepsi KB Suntik 1 Bulan

\begin{tabular}{|c|c|c|c|c|c|c|c|c|}
\hline \multirow{3}{*}{ Peningkatan BB } & \multicolumn{4}{|c|}{$\begin{array}{c}\text { Kontrasepsi KB Suntik } \\
\text { bulan }\end{array}$} & \multicolumn{2}{|c|}{ Jumlah } & \multirow{3}{*}{$\begin{array}{c}\text { Pvalu } \\
\text { e }\end{array}$} & \multirow{3}{*}{$\begin{array}{c}\text { POR } \\
(95 \% \mathrm{Cl})\end{array}$} \\
\hline & \multicolumn{2}{|c|}{ Tidak } & \multicolumn{2}{|c|}{ ya } & & \multirow{2}{*}{$(\%)$} & & \\
\hline & $\mathrm{n}$ & $(\%)$ & $\mathrm{n}$ & $(\%)$ & & & & \\
\hline Tidak Menil & 64 & 68,8 & 29 & 31,2 & 93 & 10 & 0.000 & \\
\hline Meningkat & 51 & 32,5 & 106 & 67,5 & 157 & 100 & 0,000 & $(2,643-7,961)$ \\
\hline
\end{tabular}

Berdasarkan hasil uji chi-square diperoleh nilai $p$ value $<0,05$ Peningkatan berat badan $p$

\section{PEMBAHASAN}

Hasil penelitian Mayoritas responden yang menggunakan suntik KB 1 bulan dan mengalami kenaikan Brat Badan berjumlah 157 orang $(62,8 \%)$. Hasil penelitian ini sejalan dengan penelitian yang dilakukan oleh (Erawiti, 2015) yang menyebutkan bahwa Pengguna kontrasepsi suntik di BPM Sugiyati tahun 2014 lebih 1 tahun sebesar 91,7\% dan 60\% akseptor suntik mengalami peningkatan berat badan. Hasil uji chi square diketahui $X 2$ hitung 4,628 dengan $p$-value 0,099 yang berarti tidak ada hubungan antara lamanya pemakaian alat kontrasepsi suntik dengan perubahan berat badan pada akseptor KB suntik. Dan selaras pula dengan penelitian yang dilakukan (Simbolon, 2016) didapatkan adanya perubahan berat badan berdasarkan lama penggunaan kontrasepsi suntik 3 (tiga) bulanan yang signifikan, sedangkan penggunaan KB Suntik terhadap perubahan berat badan didapatkan hasil yang tidak signifikan.

Dari hasil uji statistik di peroleh nilai $p$ value $<0,05$ Peningkatan berat badan $p$ value: value: 0,000 yang artinya berhubungan dengan penggunaan KB suntik 1 bulan.

0,000 yang artinya ada hubungannya dengan penggunaan KB suntik 1 bulan terhadap peningkatan berat badan. Dari hasil uji statistik di peroleh nilai POR: 3,357 yang artinya ibu yang menggunakan KB suntik 1 bulan beresiko mengalami kenaikan berat badan. Hasil ini sesuai dengan hasil penelitian (Sriwahyuni, 2009) yang menemukan bahwa pemakaian kontrasepsi hormonal lebih dari 1 tahun cenderung terjadi peningkatan berat badan pemakainya.

Kenaikan berat badan saat menggunakan alat kontrasepsi hormonal, ada kemungkinan hal tersebut disebabkan oleh faktor internal dan eksternal. Faktor internal berupa riwayat obesitas dari keluarga, sementara faktor eksternalnya adalah kandungan hormon pada alat kontrasepsi. Penggunaan kontrasepsi hormonal dengan kadar estrogen yang tinggi dapat menyebabkan pengendapan lemak pada jaringan tubuh. Sementara itu, hormon progesteron dapat merangsang pusat pengendali nafsu makan di hipotalamus yang 
menyebabkan akseptor makan lebih banyak dari biasanya. Progesteron mempermudah penumpukan karbohidrat dan gula menjadi lemak.

Penelitian ini sejalan dengan penelitian (Pinasti . A, 2013) pengaruh antara lama penggunaan kontrasepsi suntik dengan kenaikan berat badan pada akseptor kontrasepsi suntik. Berdasarkan uji Analisis chisquere diperoleh nilai $\chi 2$ hitung sebesar 19,018 dengan $p=0,000$, sedangkan $\chi 2$ tabel pada taraf signifikansi $5 \%$ adalah 5,991 . Dikarenakan nilai $\chi 2$ hitung $>\chi 2$ tabel yaitu $19,018>5,991$ dengan signifikansi $p$ value $<0,05$ dapat disimpulkan terdapat pengaruh yang signifikan penggunaan kontrasepsi suntik terhadap peningkatan berat badan.

Efek penambahan berat badan pada pemakaian KB suntik 1 Bulan disebabkan karena pengaruh hormon progesteron yang mempermudah perubahan karbohidrat dan gula yang dikonsumsi dari makanan menjadi lemak. Namun demikian terdapat juga beberapa usaha yang dapat dilakukan untuk mengurangi berat badan antara lain olahraga, mengkonsumsi serat makanan, mengurangi konsumsi lemak, lebih banyak mengkonsumsi protein dan serat serta adanya perubahan perilaku (Maryuni, 2016). Hal serupa berdasarkan hasil penelitian yang dilakukan oleh peneliti bahwa terdapat hubungan antara peningkatan berta badan dengan Kb Suntik 1 Bulan.

\section{KESIMPULAN DAN SARAN}

Berdasarkan Hasil analisis Bivariat menunjukkan bahwa terdapat peningkatan berat badan pada penggunaan KB suntik 1 Bulan. Hasil uji chi-square diperoleh nilai $p$ value $<0,05$ yaitu: 0,000 yang artinya ada hubungan peningkatan berat badan dengan penggunaan KB suntik 1 bulan.

Bagi instansi pelayanan kesehatan atau petugas kesehatan lain dapat memberikan konseling dan informasi tambahan tentang efek samping dalam penggunaan KB Suntik 1 Bulan terhadap Peningkatan Berat Badan serta Bagi lbu yang menggunakan KB Suntik 1 Bulan agar selalu teratur untuk suntik ulang setiap bulannya. Diharapkan juga petugas kesehatan mengetahui pola dasar pemilihan KB dan dapat membantu masyarakat khususnya WUS untuk memilih KB.

\section{REFERENSI}

Dewi Astuti, H. I. (2015). Faktor-Faktor yang Berhubungan Dengan Pemilihan Alat Kontasepsi Suntik. Jurnal Keperawatan, 11(2).

Erawiti, D. (2015). Hubungan Lama Pemakaian Kontrasepsi Suntik Dengan Peningkatan Berat Badan Pada Akseptor Suntik Depo Medroksi Progesteron Asetat Di Bidan Praktik Mandiri (BPM) Sugiyati Kajoran Magelang. STIKES Aisyiah.

Kemenkes. (2013). Situasi keluarga berencana di Indonesia.

Maryuni, A. S. (2016). Pengaruh Kb Suntik Terhadap Kenaikan Berat Badan Akseptor. Kesehatan Reproduksi, 1(1).

Pinasti . A, P. (2013). Pengaruh PEnggunaan Kontrasepsi Suntik Terhadap Peningkatan Berat Badan dan Kenaikan Tekanan Darah pada Akseptor Keluarga Berencana di Puskesmas Kecamatab Sukodono Kabupaten Sragen. Muhammadiyah Surakarta.

Simbolon, R. (2016). Hubungan Pemakaian Kb Suntik 3 Bulan Dengan Kenaikan Berat Badan Di Desa Mekar Tanjung Kec. Telukdalam, Kab.Asahan. AKBID Mitra Husada Medan.

Sriwahyuni, E. C. U. W. (2009). Hubungan antara Jenis dan Lama Pemakaian Alat Kontrasepsi Hormonal dengan peningkatan Berat Badan Akseptor. Universitas Airlangga.

Uun Undiarti, Suherni, S. T. (2015). Pengaruh Lama Pemakaian Kb Suntik Dmpa Terhadap Kenaikan Berat Badan. Jurnal Kia, 2(2).

Yuningsih.R.F. (2019). Pengaruh Implementasi Program Keluarga Berencana (KB) terhadap Penekanan Angka Kelahiran (Fertilitas) di RW 02 Kelurahan Cipadung Kecamatan Cibiru Kota Bandung Timur. UIN Sunan Gunung Djati Bandung. 